\title{
Insecticidal and repellent activity of typical monoterpenes from plant essential oils against Callosobruchus maculatus (Fabr. 1775)
}

\author{
Suelen L Reis ${ }^{1 *}$, Anieli G Mantello ${ }^{1}$, Èrica AG Rossete ${ }^{1}$, Alexandre M Cardoso ${ }^{2}$, Rene O Beleboni ${ }^{1}$ \\ From 5th Congress of the Brazilian Biotechnology Society (SBBIOTEC) \\ Florianópolis, Brazil. 10-14 November 2013
}

Synthetic insecticides and repellents have been broadly used worldwide for the control of crop pests and insects acting as vectors of human disease. Despite effectiveness, synthetic insecticides or repellents may cause serious damages to the environment and consequently to humans and animals. The growing biotechnological investigation for alternative insecticides and repellents, particularly of natural ones from plants, may conduce to higher safety and efficiency to the control of insects. Callosobruchus maculatus (Fabr. 1775) (Chrysomelidae) is a bruchid beetle that has been considered an important crop pest and also useful as model organism for development of new insecticides/repellents due several advantages such as a quick reproduction, sexual dimorphism and easy conditions of maintenance. As a crop pest, this insect, whose control by synthetic pesticides has been not straightforward, may represent an important threaten for bean (Vigna unguiculata L.) production in Brazil as well as other stored-grains cultivars in agriculture. Considering the need of new alternatives for $C$. maculatus control and the importance of monoterpenes in plant resistance against insects, the aim of this work was to evaluate the insecticidal and repellent activity of typical monoterpenes (geraniol, citral, $( \pm)$ citronellal, citronellol and eugenol) commonly found in plant essential oil against $C$. maculatus. To date, all of tested compounds presented a significant insecticidal and also repellent activity against $C$. maculates in a range of doses from 1 to $64 \mu \mathrm{L}$. The best tested compound as insecticide was the eugenol, while the best performance as repellent was accessed using eugenol. Thus, these data showed that evaluated monoterpenes presented significant insecticidal and repellent effects, which are of high biotechnological interest and useful towards the growth of agriculture worldwide.

\section{Authors' details}

${ }^{1}$ Unit of Biotechnology - Ribeirão Preto University (UNAERP), Ribeirão Preto, Brazil. ${ }^{2}$ Federal Institute of Education, Science and Technology of São Paulo State (IFSP, Matão-SP), São Paulo, Brazil.

Published: 1 October 2014

\section{References}

1. Almeida FAC, et al: Efeitos de extratos alcoólicos de plantas sobre o caruncho do feijão vigna (Callosobruchus maculatus). Revista Brasileira de Engenharia Agrícola e Ambiental, Campina Grande 2005, 9:585-509.

2. Berenbaum M: Allelochemical interactions in plants. Rec Adv Phytochem 1985, 19:139-169.

3. Brito JP, Oliveira JEM, Bortoli SA: Toxicidade de óleos essenciais de Eucalyptus spp. sobre Callosobruchus maculatus (Fabr., 1775) (Coleoptera: Bruchidae). Revista De Biologia E Ciências Da Terra 2006, 96-103.

4. Brooker DB, Bakker-Arkema FW, Hall CW: Drying and storage of grains and oilseeds Westport; AVl; 1992, 450.

5. Kéita SM, Vincent C, Schimit JP, Arnason JT, Bélanger A: Efficacy of essencial oil of Ocimum basilicum L. and O. gratissimum L. applied as an insecticidal fumigant and powder to control Callosobruchus maculates (Fab.) (Coleoptera: Bruchidae). Journal of Stored Products Research 2001, 37:339-349.

doi:10.1186/1753-6561-8-S4-P115

Cite this article as: Reis et al:: Insecticidal and repellent activity of typical monoterpenes from plant essential oils against Callosobruchus maculatus (Fabr. 1775). BMC Proceedings 2014 8(Suppl 4):P115. 